\title{
Chlorostroma vestlandicum (Xylariales): first records of the rare ascomycete in Russia
}

\author{
E. S. Popov ${ }^{1,2 *}$, L. B. Kalinina ${ }^{1,3}$, E. A. Palomozhnykh ${ }^{1,4}$ \\ ${ }^{1}$ Komarov Botanical Institute of RAS, Prof. Popova St., 2, St.-Petersburg, 197376, Russian Federation \\ 22E-mail: epopov@binran.ru; ORCID iD: https://orcid.org/0000-0001-8599-3117 \\ ${ }^{3}$ ORCID iD: https://orcid.org/0000-0002-7809-8891 \\ ${ }^{4}$ ORCID iD: https://orcid.org/0000-0002-0789-8365 \\ * Corresponding author
}

Keywords: biodiversity conservation, chorology, Dutch Elm Disease, fungi, threatened species, Ulmus.

Summary. In this paper, for the first time in Russia we report on four new occurrences of the rare xylarialean ascomycete Chlorostroma vestlandicum revealed in the course of mycological surveys of the Northwestern European Russia. Description and colour illustrations of the material studied are provided. Dutch Elm Disease as the major possible threat for the species is discussed. The species is recommended for inclusion in the next editions of the regional Red Data Books of Leningrad, Novgorod, and Pskov Regions.

\section{Chlorostroma vestlandicum (Xylariales): первые находки редкого аскомицета в России}

\author{
Е. С. Попов, Л. Б. Калинина, Е. А. Паломожных
}

Ботанический институт им. В. Л. Комарова РАН, ул. Проф. Попова, д. 2, г. Санкт-Петербург, 197376, Россия

Ключевые слова: голландская болезнь вязов, грибы, охрана биоразнообразия, хорология, Ulmus.

Аннотация. Приводятся сведения о четырех находках нового для территории России редкого аскомицета Chlorostroma vestlandicum, выявленных в ходе микологических обследований Северо-Запада Европейской России. Вид впервые обнаружен за пределами ранее известной области обитания в западной Норвегии. Дается подробное описание и цветные иллюстрации изученного материала. C. vestlandicum находится под угрозой сокращения численности из-за голландской болезни вяза и рекомендован нами для внесения в следующие редакции региональных Красных книг Ленинградской, Новгородской и Псковской областей.

\section{Introduction}

The genus Chlorostroma A. N. Mill., Lar. N. Vassiljeva et J. D. Rogers includes three welldifferentiated species of stromatic ascomycetes characterized by green or bluish green pulvinate stromata often with yellowish entostroma, brown one-celled ascospores with a germination slit, presence of lepraric acid derivatives, and mycoparasitic habit on stromata of Hypoxylon Bull. (Miller et al., 2007; Læssøe et al., 2010; Nordén et al., 2014). Miller et al. (2007) putatively assigned it to Xylariaceae s. 1. based on striking morphological resemblance to Thuemenella Penz. 
et Sacc., later Læssøe et al. (2010) noticed close affinities between Chlorostroma and Hypoxylon aeruginosum J. H. Mill., and Senanayake et al. (2015) placed the genus in the resurrected family Hypoxylaceae DC. Nevertheless, the systematic position of Chlorostroma within Xylariales is not yet corroborated by molecular phylogenetic studies.

Records of Chlorostroma are limited, and it is likely that all species of this genus are very rare. The only European member of the genus is a recently described $C$. vestlandicum Nordén, Læssøe et J. B. Jordal parasitizing stromata of Hypoxylon vogesiacum (Pers. ex Curr.) Sacc. on wych elm (Ulmus glabra Huds.) wood and up to now, known only from a couple of dozen sites in western Norway (Nordén et al., 2014). The species is currently proposed by the International Union for Conservation of Nature (IUCN) as candidate for inclusion in "The Global Fungal Red List" (http:// iucn.ekoo.se). It is considered to be a rare species restricted to localities rich in coarse dead elm wood affected within Europe by decline of U. glabra population due to Dutch Elm Disease (J. B. Jordal pers. comm.).

Two other species of the genus (C. subcubisporum A. N. Mill., Lar. N. Vassiljeva et J. D. Rogers on stromata of $H$. perforatum (Schwein.) Fr., and C. cyaninum Læssøe, Srikit. et J. Fourn. on Hypoxylon sp.) have been reported only from their type localities in eastern North America and Thailand respectively (Miller et al., 2007; Læssøe et al., 2010).

In this paper, we report four new occurrences of $C$. vestlandicum revealed in the course of mycological surveys of the Northwestern European Russia and provide a description and illustrations of the material studied.

\section{Material and Methods}

The material was collected during a series of mycological surveys of Leningrad, Novgorod, and Pskov Regions of Russia and identified by E. S. Popov. The coordinates are in WGS84 geographic coordinate system. The macro-morphological characters were described according to the observations of fresh and dry material as well as the analysis of the photos. Capitalized colour names and corresponding colour codes given are those of Kornerup, Wanscher (1978). The micromorphological structures were examined in dried material. Fragments of stroma and perithecia were mounted in $5 \% \mathrm{KOH}$ and tap water for standard light microscopy. To test the amyloid reaction of asci's walls and apical rings Melzer's reagent (MLZ) and Lugol's solution (IKI) without and with $\mathrm{KOH}$ pre-treatment were used. The number of measured morphological structures (n) is given in parentheses after corresponding measurements. The images of micro-morphological characters were captured with an AxioCam MRc 5 digital camera on an AxioImager A1 microscope (Carl Zeiss, Göttingen, Germany). The studied specimens are deposited in the Mycological Herbarium of the Komarov Botanical Institute (LE), Russian Academy of Sciences.

\section{Results and Discussion}

Chlorostroma vestlandicum Nordén, Læssøe et J. B. Jordal, 2014, Karstenia 54: 11 (Figs. 1, 2).

Stromata when fresh peltate-pulvinate to turbinate, centrally attached, $0.5-1.5 \mathrm{~cm}$ in diam., $1-3(-5) \mathrm{mm}$ thick. Outline circular, oblong or irregular. Upper surface smooth or undulating, dark olive gray (3F2-3) to dark olive brown (4F3). Margin adnate or free, rounded or sharp, often lobed or undulate, sometimes whitish pruinose. Perithecial contours indistinct. Ostioles hardly visible, $20-50$ $(-65) \mathrm{mkm}(\mathrm{n}=10)$ diam., numerous, plane or slightly umbilicate, concolorous or slightly darker than the stroma surface. Lower side sterile, black. Stroma interior solid, soft corky in texture, lighter than the surface, mustard yellow (3B6-7) to grayish yellow (4B3-4). Extractable pigments in $10 \% \mathrm{KOH}$ dark green (29D6-7).

Perithecia monostichous, globose or flaskshaped, $140-210 \times 125-200 \mathrm{mkm}(\mathrm{n}=7)$, numerous; peridium not carbonized, dark olivaceous. Internal tissue of stroma below perithecia is a dense hyaline textura intricata of thick-walled, hyphae $6-17 \mathrm{mkm}$ wide $(\mathrm{n}=10)$ with cell walls $3.0-5.7 \mathrm{mkm}$ thick $(n=$ 10 ), gelatinized and wrinkled on surface, partly with olive (3D5-3E5) incrusting pigment, especially in subcortical zone. Asci 8-spored, clavate, broadly rounded at the apex, $115-155 \times(9.8-) 10.0-10.4$ $(-11.4) \mathrm{mkm}$, pars sporifera $72-88 \mathrm{mkm}$ long, with slender stipe, 40-79 mkm long $(\mathrm{n}=11)$, with distinct refractive euamyloid apical ring (MLZ+ bb, LG+ $\mathrm{bb}), 1.8-3.0 \mathrm{mkm}$ width and $0.2-0.5 \mathrm{mkm}$ height $(\mathrm{n}=11)$; croziers present. Ascus wall thickened to $1-1.5 \mathrm{mkm}$. Paraphyses thin-walled, filiform, sparsely septate, simple or rarely branched, 3.3-4.9 mkm wide in the middle part, tapering toward the apex to $2-2.5 \mathrm{mkm}$. Ascospores unicellular, (11.0-) $11.8-13.4(-14.7) \times(5.3-) 5.6-6.2(-6.7) \mathrm{mkm}$, 


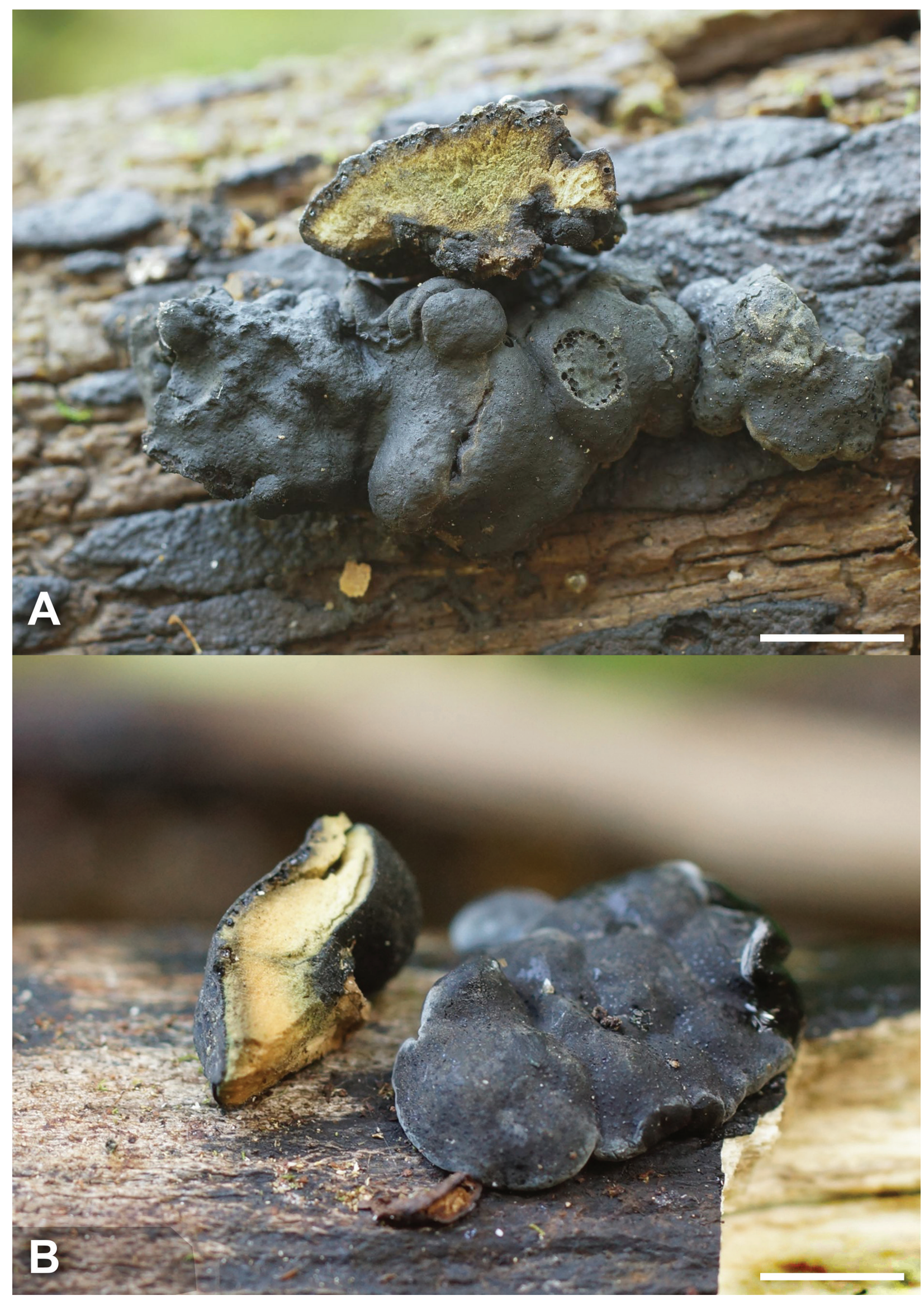

Fig. 1. Chlorostroma vestlandicum: A - Stromata on Hypoxylon vogesiacum (LE 323571). B - Stromata on blackened wood of Ulmus glabra (LE 323710). Scale bar $=1 \mathrm{~cm}$. 
1/w 1.9-2.3(-2.6) $(\mathrm{n}=42)$, ellipsoidal, slightly inaequilateral, olive brown to dark brown, smooth, with (1-)2 large lipid guttules and often with several smaller ones; de Bary bubbles sometimes present. Germ slit longitudinal, straight, reaching $1 / 3$ to $1 / 2$ of a spore length.
Material examined: "Russia, Leningrad Region, Kingiseppskiy distr., $2.7 \mathrm{~km}$ WNW of Kaybolovo village, steep slope of Suma River valley overgrown with Ulmus glabra and Alnus glutinosa (L.) Gaertn., on dead elm branch. $59^{\circ} 34^{\prime} 14.4^{\prime \prime} \mathrm{N}, 28^{\circ} 50^{\prime} 02.5^{\prime \prime} \mathrm{E}$. 11 VII 2019. E. A. Palomozhnykh" (LE 323494).

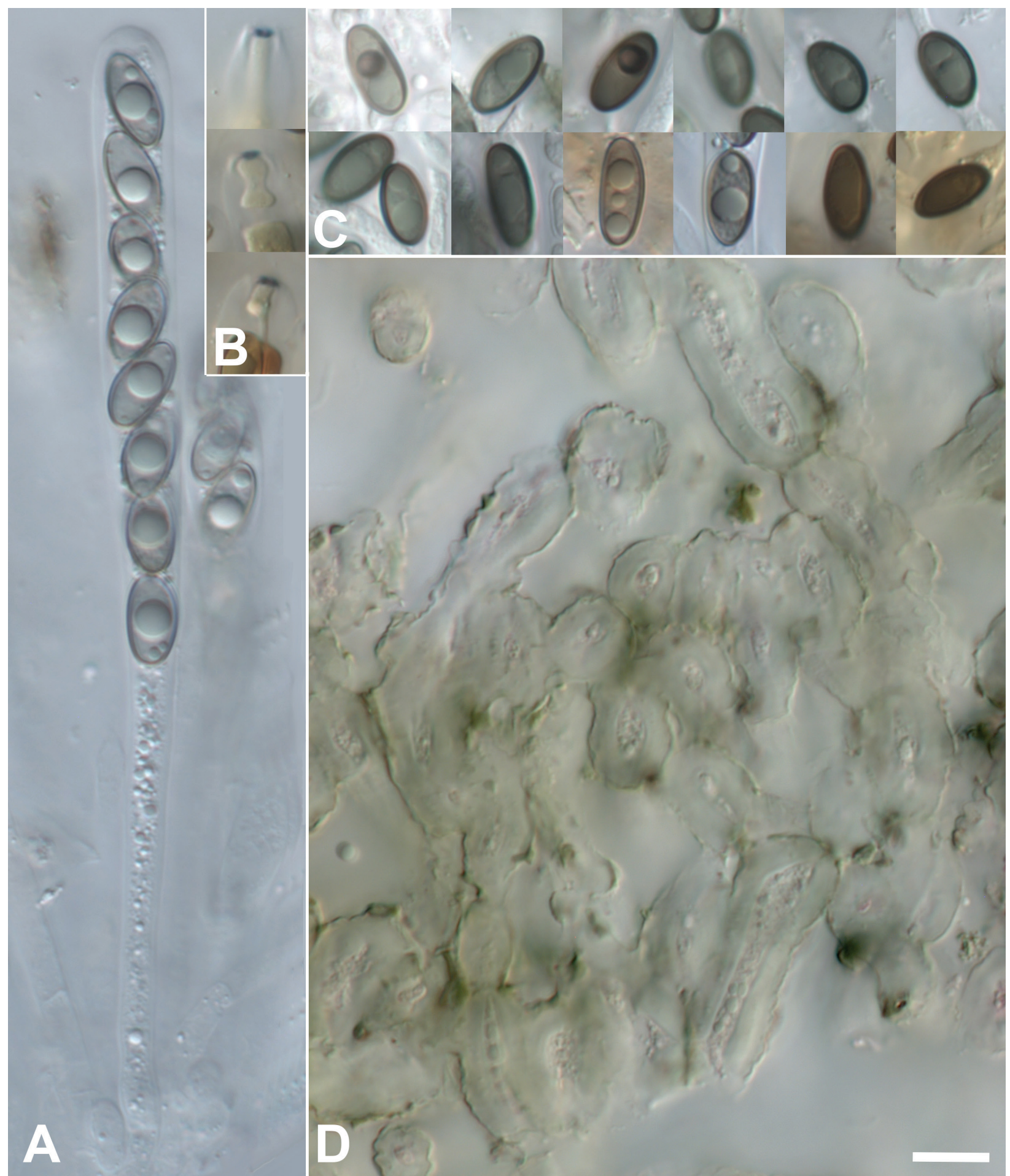

Fig. 2. Chlorostroma vestlandicum (LE 323571): A - Ascus. B - Amyloid apical ring in Lugol's solution (IKI). C Ascospores. D - Hyphae of the internal tissue of stroma. Scale bar $=10 \mathrm{mkm}$. 
"Russia, Leningrad Region, Lomonosovskiy distr., Orzhitsy, abandoned manor park with U. glabra, Tilia cordata Mill. and single Quercus robur L. trees, on dead elm wood. 5945'27.2"N, 2942'48.6"E. 15 XII 2019. E. A. Palomozhnykh" (LE 323710). "Russia, Novgorod Region, Malovisherskiy distr., $5 \mathrm{~km} \mathrm{NW}$ of Syuyska village, broadleaf forest with U. glabra, on dead elm wood. $58^{\circ} 48^{\prime} 14.5^{\prime \prime} \mathrm{N}, 32^{\circ} 16^{\prime} 00.1^{\prime \prime E} .14$ VI 2021. S. N. Arslanov" (LE 321716). "Russia, Pskov Region, Loknyanskiy distr., environs of Miritinitsy, broadleaf forest with U. glabra, Acer platanoides L, Fraxinus excelsior L., on dead elm branch. 56 $38^{\prime} 27.2^{\prime \prime N}, 2^{\circ} 48^{\prime} 17.9^{\prime \prime E}$. 14 IX 2019. L. B. Kalinina" (LE 323571).

Chlorostroma vestlandicum is a highly distinctive stromatic ascomycete. It can be easily recognized in field by the naked eye due to its mustard yellow stroma interior and frequent association with Hypoxylon vogesiacum on larger-sized wood debris of $U$. glabra. The connection between C. vestlandicum and Hypoxylon vogesiacum is well-established (Nordén et al., 2014). The last species is known in Leningrad and Pskov Regions and quite regularly, although not often observed on dead elm logs, especially in riparian forests (author's own observations). In two of the studied specimens (LE 323571, LE 321716), the stromata of $C$. vestlandicum were clearly growing on $H$. vogesiacum, in the other (LE 323494), the fungus was growing on blackened decorticated wood with remnants of some stromatic xylariaceous fungi on some distance, which is likely to be $H$. vogesiacum. The fourth specimen (LE 323710) contains a piece of corticated wood overgrown with mosses, and stromata of $C$. vestlandicum are erumpent from the cracks in the bark; no signs of Hypoxylon were seen.

Ulmus glabra declines drastically due to Dutch Elm Disease. For a long time, the disease was localized in the south of European Russia, but since the end of the 20th century, there has been a massive dying of elms in the central and northwestern regions (Gninenko et al., 2020). During last decades, the decline of elms has become disastrous in parks of
Saint Petersburg and its suburbs (Firsov, Bulgakov, 2017). The tree is assessed as vulnerable in Europe (Rivers et al., 2019). While there are no reliable data on decline of wild wych elm populations in Northwestern European Russia, the rarity of C. vestlandicum and its narrow substrate specialization allow us to conclude that the Dutch Elm Disease in the future may become a crucial threat for $C$. vestlandicum.

\section{Conclusions}

Chlorostroma vestlandicum is classified as Endangered in Norway (Brandrud et al., 2015). The new occurrences of $C$. vestlandicum reported in our study are more than $1000 \mathrm{~km}$ away from Norway populations and significantly expand the known range of the species. Considering that these three collections were made in different areas of European Russia in a short time, it could seem that the species occurs in favorable biotopes more regularly than one could expect. Nevertheless, its narrow substrate specialization and confinement to rare plant communities with elm and other broadleaved trees allow us to recommend it for inclusion in the next editions of the regional Red Data Books of Leningrad, Novgorod, and Pskov Regions. Further targeted studies of wych elm habitats are needed to clarify the status of local populations of $C$. vestlandicum and their potential threats in European Russia for making a decision on the including the species in the national Red Data Book and developing the necessary conservation actions.

\section{Acknowledgements}

The study was carried out within the framework of the institutional research projects no. AAAAA19-119020890079-6 "Biodiversity, ecology and structural and functional features of fungi and mushroom-like protists" using equipment of The Core Facility Center "Cell and Molecular Technologies in Plant Science" at the Komarov Botanical Institute of the Russian Academy of Sciences.

\section{REFERENCES / ЛИTEPATУPA}

Brandrud T. E., Bendiksen E., Jordal J. B., Hofton T. H., Larsson K.-H., Hoiland K. 2015. Sopper. In: Norsk rødliste for arter 2015. S. Henriksen, O. Hilmo (eds). Oslo: Artsdatabanken. Pp. 132-156.

Firsov G. A., Bulgakov T. S. 2017. The modern state of elms (Ulmus L., Ulmaceae) in arboretum of Peter the Great Botanic Garden under conditions of epiphytoty of the Dutch Elm Disease. Hortus botanicus 12: 278-312. [In Russian] (Фирсов Г. А., Булгаков T. $\boldsymbol{C}$. Современное состояние вязов (Ulmus L., Ulmaceae) в парке-дендрарии Ботанического сада Петра Великого в условиях эпифитотии голландской болезни вязов // Hortus botanicus, 2017. T. 12. C. 278-312). DOI: 10.15393/j4.art.2017.3962 
Gninenko Yu. I., Kolganikhina G. B., Sinkevich V. A. 2020. Dutch Elm Disease - A historical aspect in Russia. In: Modern Problems of Forest Protection and Ways of their Solution: Proceedings of II International science-practical conference dedicated to 95-year anniversary of N. I. Fedorov and 90-year anniversary of Department of Forest Protection and Wood Science. Minsk: BSTU. Pp. 80-83. [In Russian] (Гниненко Ю. И., Колганихина Г. Б., Синкевич В. А. Голландская болезнь ильмовых - исторический аспект в России // Современные проблемы лесозащиты и пути их решения: Материалы II Междунар. науч.-практ. конф., посвящ. 95-летию со дня рождения проф. Н. И. Федорова и 90-летию кафедры лесозащиты и дресиноведения. Минск: БГТУ, 2020. С. 80-83).

Laessøe T., Srikitikulchai P., Fournier J., Köpcke B., Stadler M. 2010. Lepraric acid derivatives as chemotaxonomic markers in Hypoxylon aeruginosum, Chlorostroma subcubisporum and C. cyaninum, sp. nov. Fungal Biology 114: 481-489. DOI: 10.1016/j.funbio.2010.03.010

Miller A. N., Vasilyeva L. N., Rogers J. D. 2007. Chlorostroma subcubisporum gen. et sp. nov. and notes on the systematic position of Thuemenella cubispora. Sydowia 59: 138-147.

Nordén B., Laessøe T., Jordal J. B. 2014. Chlorostroma vestlandicum sp. nov., a hostspecific mycoparasite on Hypoxylon vogesiacum from western Norway. Karstenia 54: 9-14.

Rivers M. C., Beech E., Bazos I., Bogunić F., Buira A., Caković D., Carapeto A., Carta A., Cornier B., Fenu G., Fernandes F., Fraga P., Garcia Murillo P. J., Lepší M., Matevski V., Medina, F. M., Menezes de Sequeira, M., Meyer, N., Mikoláš, V., Montagnani, C., Monteiro-Henriques T., Naranjo Suárez J., Orsenigo S., Petrova A., Reyes-Betancort J. A., Rich T., Salvesen P. H., Santana López I., Scholz S., Sennikov A., Shuka L., Silva L. F., Thomas P., Troia A., Villar J. L., Allen D. J. 2019. European Red List of Trees. Cambridge, Brussels: IUCN. 60 pp. DOI: 10.2305/IUCN.CH.2019.ERL.1.en

Senanayake I. C., Maharachchikumbura S. S. N., Hyde K. D., Bhat J. D., Jones E. B. G., McKenzie E. H. C., Dai D. Q., Daranagama D. A., Dayarathne M.C., Goonasekara I. D., Konta S., Li W. J., Shang Q. J., Stadler M., Wijayawardene N. N., Xiao Y. P., Norphanphoun C., Li Q., Liu X. Z., Bahkali A. H., Kang J. C., Wang Y., Wen T. C., Wendt L., Xи J. C., Camporesi E. 2015. Towards unraveling relationships in Xylariomycetidae (Sordariomycetes). Fungal Diversity 73: 73-144. DOI: 10.1007/s13225-015-0340-y 